\title{
RADIATION OF ULTRA-WIDEBAND ELECTROMAGNETIC PULSES BY PULSED EXCITATION OF RECTANGULAR ANTENNA*
}

\author{
S. Ašmontas ${ }^{\text {a }}$, F. Anisimovas ${ }^{\text {a }}$, L. Dapkus ${ }^{\text {a }}$, J. Gradauskas ${ }^{\text {a }}$, O. Kiprijanovič ${ }^{\text {a }}$, \\ I. Prosyčevas ${ }^{b}$, J. Puišo ${ }^{c}$, K. Šlapikas ${ }^{b}$, and B. Vengalis ${ }^{a}$

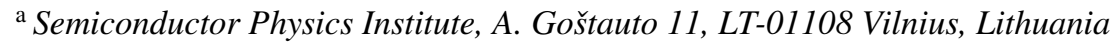 \\ E-mail: kipriol@pfi.lt \\ ${ }^{\mathrm{b}}$ Institute of Physical Electronics, Kaunas University of Technology, Savanoriu 271, LT-50131 Kaunas, Lithuania \\ ${ }^{\mathrm{c}}$ Department of Physics, Kaunas University of Technology, Studentu 50, LT-51368 Kaunas, Lithuania
}

Received 3 October 2008; revised 2 February 2009; accepted 19 March 2009

\begin{abstract}
Rectangular $\left(2.5 \times 2 \mathrm{~cm}^{2}\right)$ antennas fastened to an end of a transmission line were pulse-excited by $0.5 \mathrm{~ns}$ rise time pulses for radiation of ultra-wideband signals. Wideband horn antennas were used for receiving the signals and wideband sampling oscilloscope was used for their visualization. The signals were registered in 1-5.6 GHz frequency range and had the quasiGauss envelope form. The plane antennas made of $\mathrm{Cu}$, resistive $\mathrm{Al}$, and resistive nanostructured $\mathrm{Ni}$ thin films on supporting polyethylene terephthalate of $100 \mu \mathrm{m}$ thickness were used. It is shown that the radiation induced by pulsed excitation can be used to control parameters of resistive coatings, including nanostructured ones, during a deposition process. The metallic nanostructured thin films could be used to create plane radiating and receiving antennas having resistive elements and adapted for ultra-wideband signals. Ultra-wideband antennas with resistive nanostructured coatings, which have properties that can be changed by external electric or magnetic fields or by optical radiation, can be used for modulation of radiated pulses. Further experimental studies are proposed to elaborate metallic nanostructured thin films suitable to withstand possible damages induced by short high power electrical pulses.
\end{abstract}

Keywords: pulsed excitation, ultra-wideband signals, nanostructured thin films, plane resistive antennas

PACS: 41.20.Jb, 81.15.Jj, 81.70.Ex

\section{Introduction}

Pulsed electromagnetic radiation is used for practical applications in some of fields, among them are mining prospect, radiolocation [1], and medicine [2]. Nowadays interest in application of electromagnetic ultra-wideband (UWB) signals of picosecond and nanosecond duration is noticeably increasing. This trend is stimulated by rapid development of power electronics and by bandwidth broadening of sampling and real time digital oscilloscopes. Only during the last few years the studies and classification of UWB signals are becoming systematic [3].

In this work we use the following general expression

\footnotetext{
* Results presented at the international conference Radiation Interaction with Material and Its Use in Technologies 2008, 24-27 September 2008, Kaunas, Lithuania
}

for the UWB signal index $\eta$ representing a relative frequency band:

$$
\eta=\frac{f_{\text {up }}-f_{\text {low }}}{f_{\text {up }}+f_{\text {low }}},
$$

where $f_{\text {up }}, f_{\text {low }}$ are the highest and the lowest frequencies of the signal spectrum, respectively. The signals with $\eta<0.01$ belong to a narrow band, the condition $0.01 \leq \eta<0.25$ corresponds to a wide band, and the signals with $0.25 \leq \eta \leq 1$ belong to UWB signals.

Usually, UWB signals are wave packets having a quasi-Gauss form envelope. In order to evaluate energetic parameters of the radiated pulses having such a form, an approximation of a Gauss form envelope function can be used:

$$
s(t)=A \exp \left(-\frac{\pi t^{2}}{\tau_{\mathrm{p}}^{2}}\right) \exp \left(\mathrm{i} 2 \pi f_{0} t\right), \tau_{\mathrm{p}}=\frac{k}{f_{0}},
$$

where $A$ is the amplitude of pulse envelope, $f_{0}$ is the mean frequency, $\tau_{\mathrm{p}}$ is the effective pulse duration, $k$ is 
an appropriate coefficient. The pulse duration $\tau_{\mathrm{p}}$ is defined at the level of $A \exp (-\pi / 4) \approx 0.46 A$.

A single pulse energy, in general, can be defined as

$$
E=\alpha P_{\mathrm{p}} \tau_{\mathrm{p}},
$$

where $P_{\mathrm{p}}=A^{2} / 2$ is power at the pulse maximum, and envelope coefficient $\alpha$ depends on pulse form and defined level of pulse duration. For the Gauss envelope $\alpha$ is equal to $1 / \sqrt{2} \approx 0.707$ with $\tau_{\mathrm{p}}$ defined at the level of $0.46 \mathrm{~A}$.

The amplitude spectrum of such a signal is

$$
F(f)=A \tau_{\mathrm{p}} \exp \left[-\pi\left(f-f_{0}\right)^{2} \tau_{\mathrm{p}}^{2}\right] .
$$

One of the methods to generate UWB signals is excitation of radiating structures by current pulses [4]. Theoretical investigation of UWB signals radiated by plane antennas revealed strong dependence of the signal amplitude on geometrical parameters of the antenna and on direction of radiation [5]. Antennas with resistive elements are used for undistorted receiving of UWB signals and to shorten the duration of the UWB signals. Such antennas can radiate other UWB signals such as Gauss monocycle pulses or bipolar video pulses [3]. Today the creation of plane compact UWB antennas with resistive elements remains an important problem. These antennas could be adapted for high power applications $[6,7]$.

In this work fast rising electrical pulses were used to generate electromagnetic pulses. Electrical pulses excited rectangular antennas, including those with a resistive coating, which were fastened to the end of transmission line. Wideband pyramidal horns and sampling oscilloscope were used to visualize received signals in the frequency range from 1 to $5.6 \mathrm{GHz}$. Properties of the generated pulses and influence of resistive coating on their amplitude and form have been investigated.

\section{Radiating rectangular antennas}

Antennas of rectangular shape $(a=2.5 \mathrm{~cm}, b=$ $2 \mathrm{~cm}$, see Fig. 1) were used in the experiment. The first type of antenna was made of $\mathrm{Cu}$ foil of $200 \mu \mathrm{m}$ thickness. The second group consisted of two types of antennas made of crumpled and glassy $\mathrm{Al}$ foil of about $5 \mu \mathrm{m}$ thickness with paper support (total thickness $25 \mu \mathrm{m}$, resistance of square area $0.2 \Omega$ ).

The third group of metallic antennas were made of nanostructured $\mathrm{Ni}$ thin films prepared on a polyethylene terephthalate (PET, thickness $100 \mu \mathrm{m}$ ). During preparation PET support was cleaned by oxygen plasma processing $\left(\mathrm{RF}=13.56 \mathrm{MHz}, P=0.3 \mathrm{~W} / \mathrm{cm}^{2}, t=5\right.$

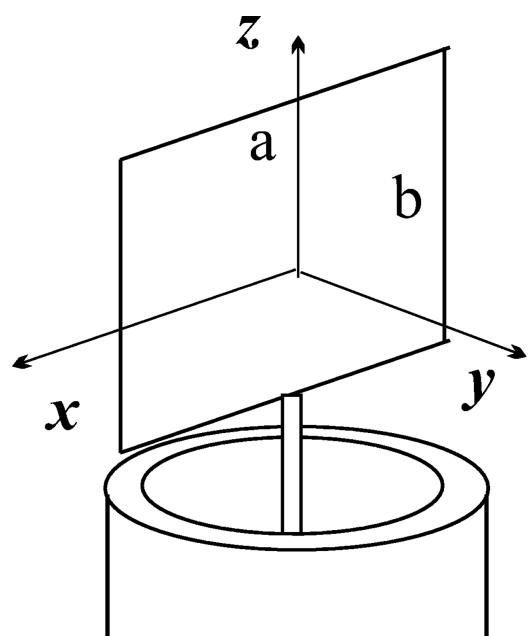

Fig. 1. Geometry of the rectangular shape antenna fastened to an end of a transmission line.

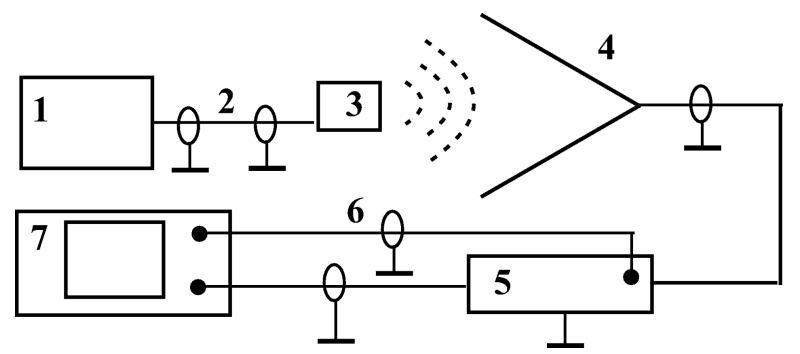

Fig. 2. Schematic diagram of the experimental set-up. 1 is nanosecond pulse generator, 2 coaxial supply line, 3 rectangular antenna, 4 receiving horn antenna, 5 delay line, 6 synchronization, 7 sampling oscilloscope.

$60 \mathrm{~s}$ ). The nanostructured Ni coating (purity $99.99 \%$, $T_{\text {melt }}=1453^{\circ} \mathrm{C}$ ) was deposited by electron beam evaporation $\left(T=80^{\circ} \mathrm{C}\right.$, residual gas pressure was $10^{-4} \mathrm{~Pa}$, deposition rate $v=1-2 \mathrm{~nm} / \mathrm{s}$ ). The film thickness during the deposition was monitored with a quartz balance technique. The temperature of the support during deposition was controlled with a precision of $\pm 0.5^{\circ} \mathrm{C}$. After thin film deposition Ni-PET structures were thermally annealed at $140{ }^{\circ} \mathrm{C}$ (below PET glassing temperature) for 30 minutes. It was found from XRD spectra analysis that the prepared nanostructured $\mathrm{Ni}$ films before and after annealing were amorphous. Atomic force microscope (AFM) study of the film surfaces showed that the size of nanostructures increased with film thickness. The average thickness of the Ni films was 10, 15, and $20 \mathrm{~nm}$ with corresponding resistance of square area 54, 48 , and $25 \Omega$. 


\section{Experimental technique}

Schematic diagram of the experimental set-up is shown in Fig. 2. A mercury-wetted relay generator was used as a subnanosecond rise time pulse generator (1). The amplitude of the pulses was controlled by power supply. The $2.5 \times 2 \mathrm{~cm}^{2}$ rectangular antenna (3) was fastened at the end of a coaxial supply line (2) connected to the generator output. Signal radiated by the antenna (3) was received by horn antenna (4) and transmitted to broadband oscilloscope (7) through delay line (5). Taking into account that the oscilloscope channel bandwidth was about $0-5 \mathrm{GHz}$ at the level of $3 \mathrm{~dB}$ (65 ps transient response) the rise time of the pulses at the end of the line (2) was chosen to be about 500 ps. Two receiving pyramidal horn antennas were used in the experiment: one having 1-18 GHz bandwidth (horn aperture $34 \times 26 \mathrm{~cm}^{2}$, length $85 \mathrm{~cm}$ ) and another of 2 $5.6 \mathrm{GHz}$ bandwidth (horn aperture $12 \times 9 \mathrm{~cm}^{2}$, length $30 \mathrm{~cm}$ ), with outputs to coaxial $50 \Omega$ cable. The distance between the antenna (3) and the centre of the horn aperture was 80 and $30 \mathrm{~cm}$, respectively.

\section{Visualized signal wave forms}

The signals were received by the horn antennas in the directions corresponding to $x, y, z$ axes. It was found that signals obtained in $z$ axis have smaller amplitude (compared to those obtained in $x$ and $y$ axes). Signals obtained in $x$ and $y$ directions had similar envelope forms and amplitudes with $z$ axis parallel to broader side of the receiving horn aperture. The signal with the largest amplitude was obtained in $x$ and $y$ directions, when $z$ axis was parallel to narrower side of the receiving aperture. It should be noted that in this case signals obtained in $x$ and $y$ directions slightly differed after 22.5 nanoseconds from the pulse beginning. Signals obtained from the $\mathrm{Al}$ foil antenna were similar to those obtained from $\mathrm{Cu}$ foil antenna, but had lower values of the amplitude. The paper and PET supports had negligible influence on electromagnetic energy absorption in the $2-5.6 \mathrm{GHz}$ frequency range.

Signals of $\mathrm{Cu}$ and $\mathrm{Al}$ antennas received by the large horn in $x$ axis are demonstrated in Fig. 3. Voltage of exciting electrical pulse from the pulse generator was 200 V. As one can see, both pulses have a quasi-Gauss envelope. Amplitude values of the signal corresponding to $\mathrm{Al}$ antenna are lower compared to those of $\mathrm{Cu}$ antenna. Similar results were obtained with resistive $\mathrm{Ni}$ antennas.

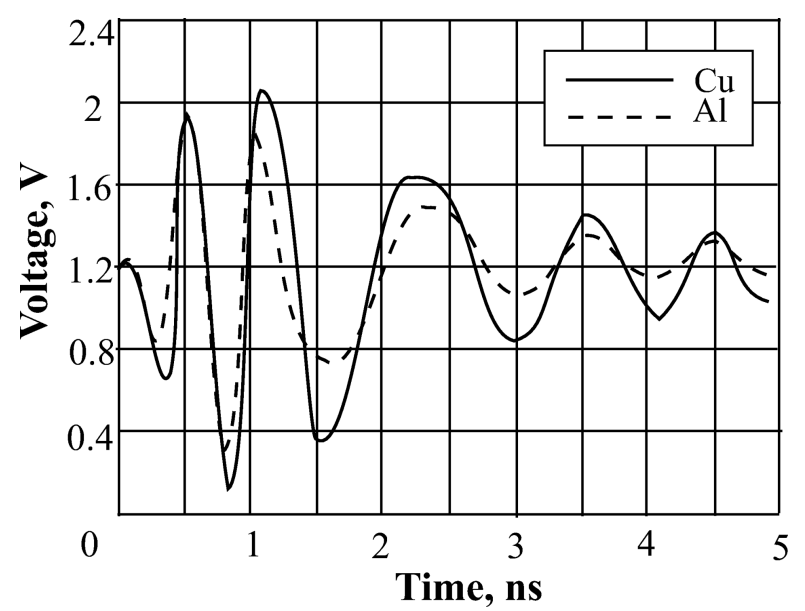

Fig. 3. Oscillograms received in $x$ axis by the large horn ( $z$ axis is parallel to the narrow side of the horn). Solid line corresponds to $\mathrm{Cu}$ antenna, dashed line corresponds to crumpled $\mathrm{Al}$ antenna.

Deflection factor is $0.4 \mathrm{~V} /$ div., sweep range is $0.5 \mathrm{~ns} / \mathrm{div}$.

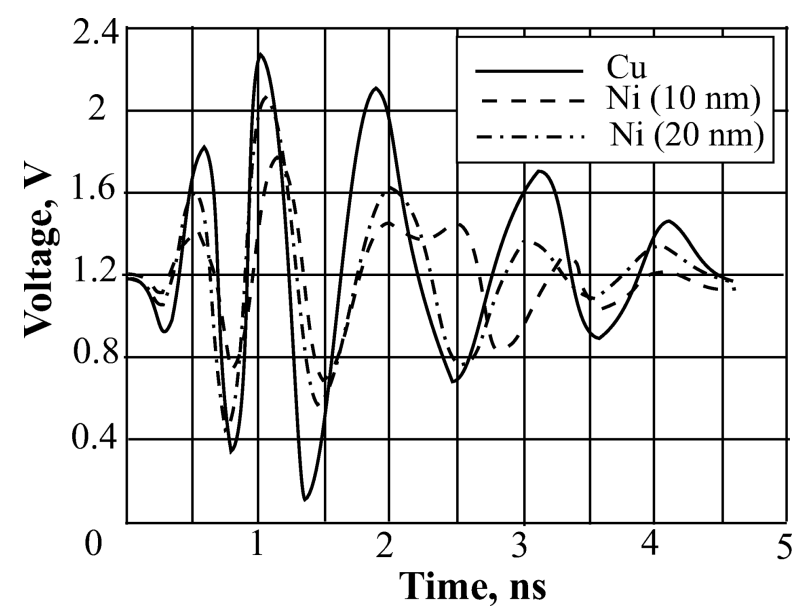

Fig. 4. Oscillograms received in $y$ axis by the large horn $(z$ axis is parallel to narrow side of the horn). Solid line for $\mathrm{Cu}$ antenna, dash-dotted line for $\mathrm{Ni}$ (10 nm thick) antenna, and dotted line for $\mathrm{Ni}$ (20 nm thick) antenna. Deflection factor is $0.4 \mathrm{~V} /$ div., sweep range is $0.5 \mathrm{~ns} / \mathrm{div}$.

Signals of $\mathrm{Cu}$ and $\mathrm{Ni}$ antennas received by the large horn in $y$ axis are shown in Fig. 4. In Ni antenna cases, one can see lower signal amplitude values and changes in signal envelope form, compared to the $\mathrm{Cu}$ case.

Figure 5 demonstrates signals received by the small horn in $z$ axis direction. The exciting electrical pulse voltage from the pulse generator was $270 \mathrm{~V}$. The signal consists of two wave packets ( $\mathrm{Cu}$ antenna case). This envelope form change is due to narrower frequency band of the small horn. It is seen that the $\mathrm{Al}$ and $\mathrm{Ni}$ antennas suppress the amplitude values of the second wave packet. It also should be noted that some changes in signal form appear with increase of the exciting pulse voltage. 


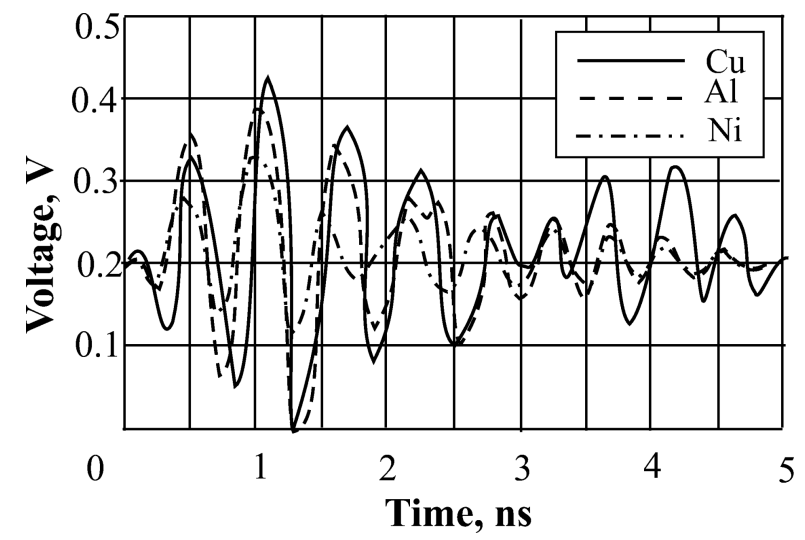

Fig. 5. Oscillograms received in $z$ axis by the small horn. Solid line corresponds to $\mathrm{Cu}$, dashed to crumpled $\mathrm{Al}$, and dash-dotted to $\mathrm{Ni}$ (15 nm thick) antennas. Deflection factor is $0.1 \mathrm{~V} /$ div., sweep range is $0.5 \mathrm{~ns} / \mathrm{div}$.

\section{Discussion of results}

The signals shown in Fig. 5 have spectrum range defined by the small horn. Application of equation (1) to these signals reveals that $\eta=0.476$, therefore even the signals with changed envelope form are characterized as UWB. Figure 3 demonstrates the signals received by the large horn. The values of $f_{\text {up }}$ for these signals are unclear and are close to the set-up wideband upper frequency. In the case of quasi-Gauss pulses the difference $f_{\text {up }}-f_{\text {low }}$ can be estimated as $2 / \tau$, where $\tau$ is the pulse length at the base; then $\eta=\left(f_{\text {up }}-f_{\text {low }}\right) / f_{0}$, where $f_{0}$ is the mean basic frequency [3]. On the basis of Fig. 3 and Eq. (1) one can obtain that $\eta=0.333$ (taking $\tau \approx$ $5 \mathrm{~ns}, f_{0} \approx 1.2 \mathrm{GHz}$ for $\mathrm{Cu}$ antenna). The index $\eta$ value denotes UWB signal. In Fig. 4 we can see that the signals received in $y$ axis are shorter than those in $x$ axis (see Fig. 3) and, therefore, they should be characterized as UWB signals as well.

An attempt to use metallic coaxial cone horn of wider band $\left(f_{\text {low }} \approx 0\right)$ was unsuccessful because of strong signal distortion due to internal reflections. For undistorted reception of UWB signals, TEM horns with two conducting plates having resistive coating are used. Resistive coating reduces the reflections and improves matching with $50 \Omega$ output. Use of the horn antennas is inconvenient because of their large dimensions. Our experiments show that $\mathrm{UWB}$ radiation of the $\mathrm{Al}$ and $\mathrm{Ni}$ antennas is sensitive to their surface resistivity. Suppression of the amplitude values of the second wave packet by the resistive antennas (see Fig. 5) indicates a possibility to use them for radiated signal shortening. Therefore, the resistive properties of thin metal films allow one to use these materials in designing plane UWB antennas. On the other hand, the radiation can be ap- plied to control parameters of various resistive coatings, including nanostructured films, during a deposition process. Further, if resistive properties of nanostructured coatings can be changed by external electric or magnetic fields or by optical radiation, then such coatings can be used in UWB antennas for modulation of the radiated pulses.

In our experiments the radiation is induced under conditions corresponding to the dipole radiation: linear dimension of an antenna should be smaller than the shortest wavelength in the signal spectrum [8]. Since the antennas are not matched with a cable and radiate mainly during the pulse front, the radiation is not effective enough. The estimated power radiated in all directions by the $\mathrm{Cu}$ antenna (oscilloscope input was $50 \Omega$ ) was of about $1 \mathrm{~W}$, while the exciting pulse power was $800 \mathrm{~W}$. The origins of quasi-Gauss envelope form of the signal are not completely clear. Obviously, the broadening of antenna's bandwidth and improvement of matching would result in increase of the radiated signal power with certain decrease of oscillation number of the UWB signal. The attempts to widen the set-up frequency band are continuing.

In order to increase the amplitude of the radiated pulses for long distance applications, it is necessary to use high power exciting pulses or to form high amplitude signals by using an antenna array. It is known that high power electrical pulses of nanosecond duration induce irreversible damage in films fabricated of non-metallic resistive materials [9].

AFM analysis of the annealed $20 \mathrm{~nm}$ thick Ni films revealed existence of nanosized semi-spheres standing out $10 \mathrm{~nm}$ above the surface. Due to nanosized structure, the Ni films could have certain features permitting them to withstand high power pulse action. Parameters of nanoscale films and nanoparticles such as melting temperature and heat conductivity are lower than those of corresponding bulk material. And vice versa, thermal expansion coefficient and heat capacity may be larger [10]. Nanoscale object heat emission is not investigated enough. Parameter $\alpha$ characterizing the heat transfer may be estimated from Newton's equation $\mathrm{d} Q / \mathrm{d} t=\alpha \Delta T$, where $\Delta T$ is temperature difference between a heated body and ambient air or liquid. It is known that $\alpha$ can reach extremely large values when dimensions of an object are comparable with submicron thickness of an interfacial air or liquid layer in the case when heat is transferred by means of heat conductivity [11]. Metallic nanostructured films formed by a controlled size-selective synthesis could be potentially perfect heat emitting materials. Therefore, they can be 
used as resistive elements in UWB antennas excited by power electrical pulses. Thus, further experimental studies are needed to fabricate metallic nanostructured thin films suitable to withstand possible damages induced by high power electrical pulses of nanosecond duration.

\section{Conclusions}

Our investigations show the generation of UWB electromagnetic radiation in frequency range from 1 to $5.6 \mathrm{GHz}$ under excitation of plane rectangular antennas, including those with resistive coatings, by fast rising electrical pulses. Radiated pulses have a quasi-Gauss envelope form. The power of the radiated signal is lower by two orders than that of the electrical pulse.

Both the amplitude and the envelope form of the UWB pulse are sensitive to the resistive properties of the antenna coatings, and therefore:

- it is possible to use the radiation to control parameters of various resistive coatings, including nanostructured films during their fabrication;

- materials with resistive nanostructured coatings can be used to create plane compact UWB antennas;

- UWB antennas, which have resistive nanostructured coatings with properties that can be changed by external electric or magnetic fields or by optical radiation, can be used for modulation of radiated pulses.

\section{References}

[1] Y. Melnik, V. Stepanchenko, and S. Shaldaev, Possibility of ultra-wideband signal usage for radar monitor- ing of meteorological objects, Radiotekh., No. 2, 53-57 (1999) [in Russian].

[2] N. Boiko, I. Safronov, and L. Tondij, AShEMIT - apparatus for ultra-wideband pulsed electromagnetic therapy, Prib. Tekh. Eksp. [Instrum. Exp. Tech. (Russia)], No. 5, 101-108 (2000) [in Russian].

[3] V. Radzijevskij and P. Trifonov, Models of ultrawideband signals, Radiotekh., No. 6, 43-49 (2006) [in Russian].

[4] J. Walter, J. Dickens, and M. Kristiansen, Modeling of pulsed radiating structures, in: Proceedings of 2 nd European Pulsed Power Symposium, 20-23 September 2004, Hamburg, Germany, pp. 231-233.

[5] L. Sodin, Pulse radiation of antenna, Radiotekh. Elektron. [Radio Eng. Electron. (Russia)], No. 2, 166-174 (1998) [in Russian].

[6] M. Jung, Th. Weise, U. Braunsberger, and F. Sabath, High power compact UWB-systems, in:Proceedings of International Conference on Pulsed Power, 27-29 March 2001, Gelsenkirchen, Germany, pp. G01/1-6.

[7] O. Kiprijanovič and F. Anisimovas, Compact highvoltage nanosecond pulse generators, in: Proceedings of International Conference „Science and Industry of Upper Lithuania region “, Panevėžys, November 8, 2002, pp. 256-260 [in Lithuanian].

[8] A. Matulis, Electrodynamics (Ciklonas, Vilnius, 2001) [in Lithuanian].

[9] S. Balevičius, High-power short EMP interaction with conventional electronic circuit, in: Proceedings of Jane's Infrastructure Security Conference, 6-7 November 2002, Washington DC, pp. 1-15.

[10] M. Werner and H.-J. Fecht, Nano-micro integration: Quo vadis?, mstnews, No. 4, 6-7 (2006).

[11] E.P. Bochkarev, V.M. Andreev, K.A. Tuzovskij, D.V. Zinov'ev, and E.Y. Pavlenko, Giant heat emission effect by submicron size bodies, Russ. Acad. Sci. Rep. 366(2), 178-180 (1999) [in Russian]. 


\title{
SUPERPLAČIAJUOSČIŲ ELEKTROMAGNETINIŲ IMPULSŲ SPINDULIAVIMAS IMPULSAIS ŽADINANT STAČIAKAMPE ANTENA
}

\author{
S. Ašmontas a ${ }^{\text {a }, F . ~ A n i s i m o v a s ~}{ }^{\text {a }}$, L. Dapkus ${ }^{\text {a }}$, J. Gradauskas ${ }^{\text {a }}$, O. Kiprijanovič a ${ }^{\text {, I. Prosyčevas }}{ }^{\text {b }}$, J. Puišo $^{\text {c }}$, \\ K. Šlapikas ${ }^{b}$, B. Vengalis ${ }^{a}$ \\ ${ }^{a}$ Puslaidininkiu fizikos institutas, Vilnius, Lietuva \\ ${ }^{\mathrm{b}}$ Kauno technologijos universiteto Fizikinès elektronikos institutas, Kaunas, Lietuva \\ ${ }^{c}$ Kauno technologijos universitetas, Kaunas, Lietuva
}

\section{Santrauka}

Superplačiajuosčių elektromagnetinių impulsų generavimui panaudotos stačiakampès antenos $\left(2,5 \times 2 \mathrm{~cm}^{2}\right)$, patalpintos perdavimo linijos gale, žadinant jas $0,5 \mathrm{~ns}$ augimo laiko trukmès elektriniais impulsais. Išspinduliuoti impulsai buvo priimami plačiajuostèmis ruporinèmis antenomis ir atvaizduojami plačiajuosčio stroboskopinio oscilografo ekrane. Šitie impulsai buvo registruojami 1-5,6 GHz dažnių juostoje ir turèjo kvazi-Gauso gaubiamają. Spinduliavimui buvo panaudotos $\mathrm{Cu}, \mathrm{Al}$ ir nanostruktūrinès Ni stačiakampès antenos. Skirtingo storio Ni sluoksniai buvo užgarinti ant $100 \mu \mathrm{m}$ storio polietileno tereftalato plokštelių.
Parodyta, kad superplačiajuosčius impulsus galima panaudoti elektrinėms plonų sluoksnių savybėms kontroliuoti jų garinimo proceso metu, o metalinius nanostruktūrinius sluoksnius pritaikyti kuriant superplačiajuostes perdavimo ir prièmimo antenas su paviršiniais rezistyviniais elementais. Tokias antenas su nanostruktūrinèmis dangomis, jautriomis išorinio elektrinio arba magnetinio lauko arba optinès spinduliuotės poveikiams, galima panauduoti plačiajuosčio spinduliavimo moduliavimui. Pasiūlyta ištirti galimybes pakeisti nanostruktūrinių metalinių sluoksnių fizikines savybes, kad jie nebūtu ardomi sužadinant galingais trumpais elektriniais impulsais. 